\title{
Poetic cosmogony in poems of Russian poets of the 18th - early 19th century
}

\author{
Alexej Petrov ${ }^{1}$, Angelina Dubskikh ${ }^{1, *}$, and Aleksandr Soldatchenko ${ }^{1}$ \\ ${ }^{1}$ Nosov Magnitogorsk State Technical University, 455000, 38 Lenin str., Magnitogorsk, Russia
}

\begin{abstract}
The research is significant due to the undiminishing interest shown by philosophers, philologists and culture experts to an eternal question of all times - the creation of the world by God. This aspect demands special consideration. That is why, the article aims to define the cosmogony as a part of the historiosophy, more precisely, the poetic cosmogony as a part of the artistic historiosophy. To achieve this aim, it is necessary to answer the following questions: 1) what is the fundamental principle of the world (universe), and is the poet focused on this particular problem? 2) what does this fundamental principle consist of? what are the constituents of the world? 3) how does it show itself? where is it situated? where does it exist? how did the world come into existence? The answers to these questions can be provided not only by religion and theology but also by science, philosophy and mythology. The analysis is carried out on the material of cosmogonical poems of four Russian 18th-19th century poets: "World's Creation. Panegyric Song" (1779-1782) by A. N. Radishchev, "Reflection on World's Creation Based on the First Chapter of Genesis" $(1784,1804)$ and "The Fate of the Ancient World or the Flood" $(1789,1804)$ by S. S. Bobrov, "Matter" (1796) by P. A. Slovtsov, "Song to the Creator" ("Pesn' Sotvorivshemu vsja") (1817) by S. A. ShirinskyShikhmatov. The conducted research found out, that all authors of the above writings put into verse versions of the so-called cosmogonic myths reputable for them, which describe how the universe originated, more or less. Four poets rely in their cosmogenesis reflections on some myth invariants to be found in the Old Testament [6], but these are the variants, and sometimes even concepts, alternating to the Bible determine an individual diversity of historiosophical constructs of our "metaphysical" poets. The material from this article can be used in teaching the following disciplines: history, 18th-century Russian literature and philosophy.
\end{abstract}

\section{Methods}

The main method of the present research is the method of philological interpretation, based on the historical-literary method. The comparative method used in the work allows correlating Russian poets' texts of the turn of the XVIII-XIX centuries (S. S. Bobrov, A. N. Radishchev, P. A. Slovtsov, and S. A. Shirinsky-Shikhmatov).

\footnotetext{
* Corresponding author: angelina.dubskikh@ mail.ru
} 
As God's creation of the world subject is directly connected with the historiosophical works of thinkers of different years, we also use the historical-philosophical method.

The methodological basis of the article is the Russian and foreign literary critics and philosophers' ideas: the role of religion in the Enlightenment [7], the concept of metaphysical pathos [8], the Orthodox theological context in the odic works of the 18thcentury poets [9].

\section{Introduction}

Reflections on God's creation of the world appear as a literary theme in the new Russian poetry somewhere at the turn of the 1770 s-1780s.

It must be borne in mind that religious and philosophical poetry phenomenon of the XVIII century arose in the fusion of Christian dogma, Freemasonry, philosophy and several scientific disciplines.

The metaphysical pathos was the 18th- century poets' mean of expressiveness.

Sergei Bobrov was, apparently, the Russian poet who first expressed a special "metaphysical pathos" that gradually matured in our poetry since the "Multicolor Garden" ("Vertograd mnogocvetnyj") by Simeon Polotsky in a conscious, consistent and distinct manner. We mean the eternity pathos as "aesthetic pleasure, which gives us a void abstract idea of firmness" [8] and which almost all Russian poets of the 18th- early 19th century enjoy.

The American philosopher and idea historian A.O. Lovejoy introduced the concept of metaphysical pathos and its types. "An example of metaphysical pathos", Lovejoy explains primarily speaking about philosophical creativity, "is any description of the nature of things, environment, in terms that awaken, like verses, their associations, a kind of empathy, a congenial mood or a system of feelings by the philosopher or his readers" [8]. Obviously, philosophers and artists are highly "sensitive" to this pathos. Their inner mental structure enable for them expressing the spiritual quest of their era and its unconscious mental habits more completely, as well as detecting, for example, an intellectual fashion.

Metaphysical preferences to be addressed by this section were reflected in the Russian poetry somewhere in the late 1770 s - early 1780 s, when well-known and anonymous authors considered the world's creation by the God. This subject is in focus of one of the well-known poems of the 18th century, "God" ("Bog") by G.R. Derzhavin (1780-1784). Along with the eternity pathos, it is inspired by both incredibility and transfiguration pathoses. The latter making sense of the world's creation verses is of a particular interest for us. The aim of the article, therefore, is to consider the historiosophy of the pathos transformation, that is the focus of lyrical works on the creation of the world.

\section{S. Shikhmatov's traditional Bible cosmogenesis}

The creation subject of the 18th-century Russian poets is the God of the Old and New Testaments, but they assume degree of His participation at cosmogenesis differently.

Shikhmatov is nearest to the traditional Bible cosmogenesis. His "Song ..." ("Pesn'...") [4], a very lengthy lyric metaphysical poem of 696 verses, is an expanded paraphrase of the Hexaemeron, the Old Testament legend about the days of creation (Gen. 1-2, 4) and a number of psalms. Duke Shikhmatov as a convinced Christian, a future monk, has no doubts that the God is good and His immeasurable goodness is the origin and source of creating. He is the only Creator of visible world: cosmic bodies, powers, inanimate and animate nature: 
Vezde, vo vsem, pri svete very / My zrim nezrimago Tebja; / Ty blag - i blagost'ju bez mery / Preizlijalsja vne sebja; / Na noshh' nichtozhestva unylu / Prizrel - i v nej blesnul razsvet, - / Ispolnil vechnyj svoj sovet, / Vozdvigsja i obleksja v silu / I prepojasalsja na trud; / Sozdal - i mir Toboj sozdannyj, / Hram slavy Tvoeja prostrannyj, / Ves' blagosti Tvoej sosud [4].

As in the Book of Genesis, the God creates the world in Shikhmatov's poem by calling it, that is, with His Word. "You said" - is the main "creature formula" in "Song..." («Pesn'...”): Ty rek - i vodruzilis' gory < ..> / Ty rek - i svetlye plodami / Dreva vet'visty vozrasli $<\ldots>>$ / Ty rek - i tvar' odushevlenna / Dyhanija prijala dar $<\ldots>$ / Ty rek - i se iz carstva noshhi / Stremjatsja voinstva svetil etc. [4].

The last verses by Shikhmatov are devoted to the first coming of Christ and His redemption of human sins, thus filling the "formula of creation" with a theological content: the creation of the world by the Word means that God the Father created the visible and invisible world through his Only-Begotten Son under the influence of the Holy Spirit [10].

In accordance with the latter and spirit of the Bible (Gen. 1, 11-12, 20, 24), the God in Shikmatov's poem provides his creatures including inanimate ones with a creative power: Ty rek - i siloj odarenna / Rastit' zhivyja veshhestva, / Zemlja krasno preispeshhrenna / Javilas' v rize torzhestva $<\ldots>>$ / Razdalsja vnov' glagol vsesil'nyj, / I sushe, spjashhej sred' morej, / Duh zhizni izlijav obil'nyj, / Velit chadotvorit' zverej: / I susha, vsjudu v podnebesnoj, / Vozchuvstvovav chto Vyshnij shhedr, / Igraja zybletsja ot nedr; / Ispolnjajas' siloju chudesnoj / Bezdushna dyshushhih razhdat', / Iznosit ih nesmetny rody, / Vdaet hraneniju prirody, / O chadah veselitsja mat' etc. [4].

This understanding remains relevant for all metaphysical poets.

\section{N. A. Radishchev's motive of the creative God's Word}

The motive of the creative God's Word becomes the main one in Radishchev's "Panegyric Song" ("Pesnoslovie"). While, according to Shakhmatov, the Word is pronounced by the God, i.e. is a "material composition" [5] of entities being created, Radhishchev's oratory depicts a special character, the Word. It is the God himself and contemporary His first creature and creating tool: Bog / No chto / Nachnem? / Rechem: / Vozljublennoe slovo, / O pervenec menja! / Ty iskoni gotovo / Vo mne, ja ty, ty ja. / Tebe ja navsegda vruchaju / Vladychestvo i vlast' moju, / V tebe ljubov' ja zakljuchaju, / Toboju mir da sotvorju. / Ispoln' bozhestvenny obety, / Javi tvoren'em bozhestvo, / Ispoln' premudrosti sovety, / Tvori zhizn', silu, veshhestvo. / Toboju ja proslavljus', / Bezdejstvija izbavljus', / Ty to javish', chto ja vozmog, / A ja v sebe pochiju, bog [1].

It should be noted that the Word God is at the same time the Love, the force providing " $<\ldots>$ everything in the world with life and start". Radishchev is the only of the authors under consideration who highlights the role of the (Divine) Love at creating. It will be recalled that Bobrov dedicated a special poem to the mythopoetic idea originated in preChrist time in 1785 .

\section{5 "Reflection on the World's Creation ..." by S. Bobrov}

While describing the origin of the universe in the poem "Kingdom of Universal Love," («Carstvo vseobshhej ljubvi») Bobrov omitted God the Almighty. He certainly could not do it in "Reflection on the World's Creation ...", ("Razmyshlenie o sozdanii mira...") partially paraphrasing the "Genesis" ("Kniga Bytija"). However, this poem is quite far from Christian orthodoxy in general and from the first chapter of the Genesis in particular. L. Zayonts believes that the poet replaces the God-Creator with the "God-Thinker" [11]. We 
believe that the 20-year-old "metaphysician" and "visionist" not only considers these two Divine modes as equals in the "first work of his muse", but also represents himself as a thinker-eclecticist. He equally understands and has insight into the antique and ancient Oriental mythologies, the Bible and the Apocrypha, ancient philosophy, modern natural science and mystical teachings. They all answer his question "how did creation occur?" Another question concerning Bobrov, unlike, for example, Radishchev and Shikhmatov, is "what preceded the creation?" or, in other words, "what is Chaos?"

Let us cite the relevant fragments of "Reflection on the World's Creation ..." ("Razmyshlenie o sozdanii mira ...") with a description of the motives contained, which do make up the pathos of eternity and transformation highly valued by Bobrov.

The soul of the poet flushed with rapture wants to penetrate into "an immemorial eternity", i.e. to see what preceded the creation and what is "incomprehensible to for man's reason": Open a secret door, you, pre-time pre-eternity! [2].

Contrary to expectations, the "eternity" is illuminated, and although it is an "abyss", this is a place where: Gde svet - triluchnyj svet sijal soboju sam, / V bezmolvii svjatom velichestvo skryvaja, / I blesk bozhestvennyj po bezdne razlivaja [2].

This abyss "accommodates" the Time/Eternity: Tot dlinnyj rjad vekov, kotoryj v mrake ves' / Ot strashnoj protjazhen predvechnosti do dnes' [2].

Apparently, a boundless Ocean is in the same abyss, but, most likely, the very abyss is the Ocean, which is consistent with the Bible [10]:

Padu ja v Okean, - v bezdonnom more vlajus', - / Ne zrja bregov drozhu, - ne zrja sebja terjajus', / I ne mogu otkryt' somknuvshihsja ochej / Pri bleske ognennyh nad bezdnoju luchej [2].

As Bobrov suggests, the Creator dwells in this "abyss-ocean" illuminated by the "firstborn light": O duh Prorocheskij, - Duh Bogom vozdoennyj! / Povezhd', ne zdes' li sej Tvorec uedinennyj? / Ne zdes' li onoe vsesil'no Bozhestvo, / Pred kem zachatoe trepeshhet estestvo? [2].

This detailed mythopoetic image of what existed "before time" and "before eternity" (Bobrov does not yet use the words nothing and Chaos) partly reminds the Old Testament's Tehom (Chaos), about which it is said: "And the earth was waste and without form; and it was dark on the face of the deep: and the Spirit of God was moving on the face of the waters" (Gen. 1, 2). However, pre-Biblical, for example, ancient Egyptian, cosmogonic ideas about the original ocean are also conceived in it. This ocean is characterized by "nonexistence, absence of heaven, earth, created world" and there is "a creator" in it [5].

The God the Creator has a plot, a "drawing of material worlds", according to which He is going to create: Se obraz on sushhestv ne sozdannyh chertit, / I budushhee ih dvizhen'e umo-zrit! <..> [2].

Bobrov emphasizes that human language cannot depict such a "wonderful phenomenon" as "the creation created miraculously in eternity", and uses the most common biblical "formula of transformation" known from the non-canonical Old Testament's II Maccabees (124 B.C.): $<\ldots>$ suddenly, something was started from nothing... $<\ldots>$ [2].

However, he specifies later as involved in natural science issues of the century:

However, something is not a dream, but a substance start.

By the way, the substance as a creation material or result attractsattention of all metaphysical poets.

Other reflections by Bobrov are already far from the Hexaemeron and, despite the value of the motive of creation with a word, are correlated rather with antique pre-scientific and mythopoetical ideas of Chaos "as a principle and source of every formation" [5]:

Se v tajnoj mrachnosti sokryto veshhestvo! / Se v chreve Haosa lezhashhe estestvo, / Vokrug ob\#emlemo vserodnoju vodoju, / Nad koej vechna noch' ispolnennaja t'moju, / Kak chernyj zanaves opushhennyj visit, / Gde slovo ot otca rodjasja, vse rodit! / Tam semena 
sushhestv rastki svoi puskajut; / Sii rastki plody na vetvi razdeljajut. / Stihii spornyja ne znaja prav svoih / Vooruzhajutsja protiv sebja samih. $<\ldots>[2]$.

Dispute of powers - fire, water, earth and air- is resolved by the creating ghost that was "spilled" over them and flew over the water on the "vital wings". A kind of culmination of cosmogenesis "as per Bobrov" and one of the peaks of the transformation pathos in the poem is an orphic cosmogonic myth of the world's egg [5]. The Creating Spirit that cannot always be associated with the Spirit of God in Bobrov's writings: Grel mira jaico, gde vse eshhe smesilos'; / Obrazoval rastok; - sogrel; - ono razkrylos'. / Ljubov' vtekaet v smes', i smes' priemlet chin; / Dyhan'e pervoe - hvala vine vseh vin, / Chto zhivotvornoju usmeshkoj ozhivljala, / I miru mudroe dvizhen'e darovala.

After the Spirit, the World Egg and the Love have given rise to life and motion in the world, the matter provided with creating capability enables a series of cosmogonic acts [11] which formally coincide with the third (creation of water, land, plants) and the fourth (the creation of heavenly bodies) days in the Hexaemeron. Nevertheless, the diagram proposed in the Bible does not always remain reputed for Bobrov. For example, he does not "count the days" and describes creation both as a one-stage process occurring here and now and as a discrete, stage-by-stage one.

The fifth "day of creation" as in the Hexaemeron turned out to be the most "problematic" for the poet. On this day, the God said, "Let the waters be full of living things, and let birds be in flight over the earth under the arch of heaven". And God made great sea-beasts, and every sort of living and moving thing with which the waters were full, and every sort of winged bird (Gen 1, 20-21). So, the world's of Bobrov that claims for harmony simply lacks these creatures.

After the cosmic bodies had been created and the day just had passed (from sunrise to sunset and until the moon appeared), the Time was born. Its image in Bobrov's poem is mediated by literary tradition - the genre of spiritual odes. This is the lifetime of the Christian: it flows forward, has an end and is not appreciated by man:

Lish' bylo pervoe dvizhen'e sih teles: / Udaril chas; - no zvon ego togdazh' izchez; / A vremja, - skol' legko v pered - v pered bezhalo? / Eshhe togda ono plachevno povtorjalo, / Chto my vsegda ego terjaja budem zhit', / Zabyv kak vdrug sud'ba prervet zhivotnu nit'. / Bezpechnyj smertnyj, zri! - se vremeni zachalo! / No vechno li ono techen'e vosprijalo? [2].

The process of creation ends in "Reflection on the World's Creation ..." ("Razmyshlenie o sozdanii mira...") with making "the beast of the earth after its sort, and the cattle after their sort beasts and reptiles" (Gen. 1, 24-25), and then the man by the earth itself but by the Creator's "call" ("Let there be, the creating powerful voice said"). The remainder of the poem is a reminiscence of the second and third chapters of Genesis, a tale of the fall of the man and his Expulsion. Here, Bobrov manifests the idea of an "infinite chain of beings".

\section{P. A. Slovtsov's "Matter"}

This idea becomes one of the most important in the work of the fourth metaphysical poet, Slovtsov. In his poem with a programmatic and, most likely, polemical title "Matter" ("Materija"), a teacher at the Tobolsk seminary and part-time preacher almost completely ignores biblical cosmogony and creationism. As the author wanted to assure the reader, it was not metaphysics, but physics that interested him. He accompanied the name of the poem with a note: "The writer of this play wanted only to test whether physical truths can be offered in verse". Strictly speaking, deep and majestic poems about "physical truths" were created in Russian literature half a century ago. Moreover, if Slovtsov could not have known about the "Theoptia" ("Feoptija") by Trediakovsky, he could not fail to be aware of metaphysical and natural philosophical poetry by Lomonosov. 
In the picture of cosmogenesis depicted by the poet of the late 18th century, the God does not participate in the process of creation, we only know that He

$<\ldots>$ rests over the centers' center / and rotates worlds with a high hand [3].

The Creator is truly replaced by the matter, and Slovtsov is close here to Bobrov's opinion that the "substance", i.e. the matter [12] possesses a life-giving power and forms "three kingdoms of nature": inanimate nature (ores, minerals, etc.) - Flora - the animal world ("from worm to verbal livings").

Slovtsov, like Bobrov, is interested in the state of the world "before creation", the Chaos appearance: Poka v stranah neozhivotvorennyh / Nedvizhima chernelas' pustota; / Poka v sih sumerkah nesotvorennyh / Ne projasnjalas' vechna gustota; / Poka v prostranstvah solncy ne dyshali / I gromy v atmosferah ne stonali, - / Dotole - i punkt ne sushhestvoval, / I tonkij atom $v$ bezdne ne letal [3].

This Chaos is physical: an empty and at the same time "dense" space. He is not created by anyone and therefore eternal. It has neither life, nor motion. Curiously, "build-up" of the space presupposes, according to Slovtsov, the presence of cosmic objects and air, and, hence, the center of the universe ("point") and primary elements (atoms) making up the matter.

While Slovtsov and Bobrov describe the image of Chaos in several verses, Radishchev has this important cosmogonic image. His historiosopheme is made up of individual characteristics, replicas given to different characters. This way of representation is the more so interesting because the fragment of the oratorio not completed by Radishchev, "Creation of the World", can be called a "prehistory" of the creation. The God and the Word are only going to create ("Well, shall we start?", "Let's start creating - what am I waiting for?" [1].). The work ends with the episode of "firmament" creation corresponding to the second day of the Hexaemeron. What do we learn about Chaos from Radishchev's "Panegyric Song" ("Pesnoslovie")?

It is an eternally existing limited space immersed in darkness and silence, devoid of life, motion and time dimension. It is resided by the Though-God, Love-God only: Tako predvechnaja mysl', osenjajas' soboju / I svoego vsemogushhestva vo glubine, / Tako veshhala, egda vse pokrytye mgloju / Pervenstvenny semena, opochiv v tishine, / Dejstvija chuzhdy i zhizni vostorga lezhali, / Vremeni kruga miry kogda ne izmerjali [1].

Although the God creates the "substance" first of all, the Chaos appears as a material non-being too- "elastic ancient nothing". Along with "elasticity", the Chaos also has the "length", but, as we noted, a limited one because the God wants to "expand his limits". Finally, the Chaos has a volume, it resembles a certain warehouse, where primary seeds, time, and motion, and substance are stored waiting for the transformation, revitalization: $<\ldots>$ Da okrepnet v tverd' puchina, / Neizmerima ravnina, / Gde prostranstvo dnes' zhivet. / Ozhivis', telesno semja, / Priimi nachalo, vremja, / I dvizhen'e, veshhestvo, / Tverdost' telom, / Zhizn' dvizhen'em, - / Se veshhaet bozhestvo [1].

Before Bobrov, Radishchev even describes the moment of transition from non-being to being: Bozhestvenna utroba rdeet, / Klubja v rozhden'e veshhestvo, / Ljubov' nachal'no semja greet, / Tvoren'em uzrish' bozhestvo [1].

If Radishchev's "Love" ("Ljubov"') and "primary seed" and Bobrov's "Love" ("Ljubov"') and "world's egg" apparently originate from the mythopoetics , the myth, whether biblical or ancient, is not recognized by Slovtsov as an explanatory cosmological paradigm. Although the poet is looking for the answer to the same question as his predecessors: Kakim natura pereshla putem /

Mezhdu nichtozhestvom [12] i bytiem? - [3].

he relies on another base- scientific knowledge, "physics", "materialism".

Slovtsov completely exclude extra-historical, extra-natural, divine forces from space "creating" from chaos. The material world, or the universe, appears either with the Time 
and Motion, or because of their emergence: No lish' podvinulis' vremjan kolesa, / I chut' tronulas' os' godin i let; / Chut' potrjaslas' tvorenija zavesa, / Vdrug hlynula materija v ves' svet [3].

First, planets are born than their atmospheres: Povsjudu stelet - vsjudu bryzzhet sfery / I oblivaet ih v vozdushny atmosfery [3].

The space being empty before is filled: Vsjo polno - net malejshej pustoty, / Ot centra do poslednej vysoty [3].

The poet declares the motion as a main law governing the material world, inanimate and animate nature: Dvizhen'e est' povsemstvennyj zakon, / Na koem veshhestvo vozdviglo tron. $<\ldots>$ / Dvizhen'e, serdce zhiznennyh javlenij, / Daet primetit' b'jushhij pul's sushhestv $<\ldots>[3]$.

Slovtsov does not deny (in the note to the poem) existence of a spiritual, supersensible world, but is inclined to believe that everything is material. He even bring into challenge the Christian dogma that God is the Spirit (Jn. 4, 24): Materija, vse massy obrazuja / I beskonechnu cep' sushhestv svjazuja, / Ob\#emlet vsjo do zadnego kol'ca, / Ot gruboj glyby dazhe do tvorca [3].

Whereas the motion does not have qualitatively different forms and is reduced as such to, as we understand Slovtsov's opinion [12], to animateness, sensitivity of the matter manifesting in varying degrees or quantities. This form takes the idea of the "great chain of being" to the materialistic metaphysical poet of the late 18th century: Vsja raznost' zhizni v raznosti dvizhen'ja, / A v protchem vse ravno rastut kak grib; / Agaty, litofity, prozjaben'ja, / Polip, orangutang i karaib

Ravno zhivut i perehodjat v rosty, / Imejut pishhu, silu, plod, narosty / I, mozhet stat'sja, chuvstvennyj organ; / Kto ispytal, ne dyshit li tjul'pan? [3].

\section{Conclusion}

By the end of the 18th century, the religious and philosophical mode of Russian poetry, which included spiritual and physico-theological verses, was enriched with "metaphysical" verses. The core of metaphysical poetry is cosmogonic and cosmological themes.

The most general diagram of the cosmogenic myth is as follows: "Someone has created something (one) somehow". Therefore, a researcher of poetic cosmogonies may seek answers to questions who appears as a subject of creation in the writing; what/whom exactly the creator builds up and in what sequence; why and how he does it.

As we can see, the pathoses of cosmogonic poems that were considered in the above paragraph are very different; they contain individual versions of the archetypal creation story.

These differences can be represented in the form of certain polarities, extreme points, located on the same axis - "from ... to ...":

- from abiding faith in creation by the Word to the recognition of the self-organization of the material world and neglect of the spiritual world;

- from praise of a man as to the Lord of the Nature to his fusion in a number of other beings.

Besides the substance as a creation material or result attractsattention of all metaphysical poets.

The matter vivifies the complete world and enjoys a creative power. This thesis generally does not contravene the Bible, but when being consistently applied, assumes some independence of the creation from the Creator. Slovtsov appeals to the Higher Power only when he faces the riddle of transition from "insignificance to being". Thus, we would designate the metaphysical pathos of the poem as of 1796 as one of deification of the matter creating the life. 


\section{References}

1. A. N. Radishhev, Poems (Leningrad, 1975)

2. Dawn of the Midnight or Contemplation of the Glory, Triumph and Wisdom of Crown, Battle and Peaceful Geniuses of Russia with Didactic, Erotic and Other Successions in Verse and Prose Experiments by Semyon Bobrov. Parts 1-4 (St. Petersburg, 1804)

3. Poets of 1790s-1810s. (Leningrad, 1971)

4. Song to the Creator. A poem by Duke Sergiy Shikhmatov, Member of the Imperial Russian Academy. V Sanktpeterburge (1817)

5. Peoples' Myths. Encyclopedia in 2 volumes (Moscow, 1997)

6. Aleksandr Men', Bibliological Glossary: 3 volumes (Moscow, 2002)

7. E. Klein, Religion and Enlightenment in the 18th Century: Derzhavin's Ode "Bog" (St. Petersburg, 2004)

8. A. Lavdzhoj, Great Genesis Chain. Idea History (Moscow, 2001)

9. M. Levitt, The Ode as Revelation: On the Orthodox Theological Context of Lomonosov's Odes. Slavic Almanac, 2003-2004, 5. (2004)

10. Law of God (New York, 1987)

11. L. Zajonc, Natura naturans: on Poetics of Anthropomorphic Landscape of Semyon Bobrov (Moscow, 2007)

12. Dictionary of the Russian Academy. Parts 1-6 (St. Petersburg, 1794) 